\title{
VALUE CHAIN ANALYSIS FOR DERIVEDPRODUCTS FROM PADDY: A CASE OF KARNATAKA STATE
}

\author{
Nagaraj BV ${ }^{1} \&$ Dr.Y. T. Krishnegowda ${ }^{2}$ \\ 1. Dept. of Operations, Kirloskar Institute of Advanced Management Studies, \\ Harihar, Karnataka, INDIA \\ 2. Dept. of Management Sciences, Maharaja Institute of Technology, Mysore, \\ Karnataka, INDIA
}

\begin{abstract}
Paddy soon after harvesting, duetoits importance as basic food, the largest area under cultivation and the prevailing agro economic conditions of farmers, constitutes a wide length and partners in its supply chain. Once paddy is hulled in mills it gives the main product rice, cut rice and by products husk and rice bran. This paper attempts to find out through empirical research, the practices, end products and estimates of value creation, value realization and value loss to the stakeholders across its extended value chainof paddy in the state of Karnataka.

With the existing estimates for legitimate variables of the analysis, it is found that supply chain of paddy is a very complex processdominatedbynetwork of intermediaries called "mill owners and stockists" who make an investment worth not less than Rs.8000 Crores.(where $\$ 13.3$ bn should be $\$ 1.33$ bn) every year during harvesting through stocking, milling and packing and create a value above $45 \%$ of their investment in the value chain. In the process it is observed that farmer is the only stakeholder who is paid least and supply chain management of paddy suffers from huge losses to the government as more than 65\% farmers sell paddy to the local agents of "mill owners and stockists". Taking stock of the issues and opportunities, a conceptual model is suggested using e-governance and Public Private Partnership $(P P P)$ in managing the supply chain of paddy which ensures fool proof mechanism not only to control prevailing losses but also arrives at a unique wealth creation opportunity, which can redefine the face of agricultural developments in the state.
\end{abstract}

Key Words: Valuechain analysis, Supply chainanalysis, Focal Firm\& PPP

\section{Introduction}

Paddy is a food crop in India with largest area under cultivation contributing to about $20 \%$ of its world production. Rice the cereal inside the hull of the paddy is used as the staple food in India and $2 / 3^{\text {rd }}$ of the world as well. Karnataka stands $5^{\text {th }}$ (4388 $\mathrm{kg}$ of paddy / Ha) in rice productivity and $12^{\text {th }}$ in its area under coverage (1.416 million Ha, 2011-12) in India.

In India, lot of thrust is given for its efficient cultivation practices through government organizations like ICAR,State Agricultural Departments and Agricultural Universities across the state. These organizations have initiated many programmes through their units like KrishiVagyanKendras (Agriculture Science Centres), Research stations, RaitaSamparkKendras (Farmer Facilitation Counters in Karnataka) working amidst rural places across the nation to improve productivity at the farm level by educating farmers with recent techniques, information and scientific approaches of cultivation to ensure better value to the efforts of farmers dependent on agriculture. 
In Karnataka many varieties of paddy (both scientifically / traditionally developed) are cultivated in almost all districts as per the suitability of agro climatic conditions. Out of 31 districts, 14 districts produce high yielding (more than $2750 \mathrm{~kg}$ paddy /Acre) fine quality rice.

Unlike other cereal foods, paddy after initial hulling process, gives vide range of products viz., fine rice, cut rice, derived products (from large sized varieties) like Poha (known as Avalakki in Kannada), stuffed rice products (known as Churumuri / Mandakki in Kannada) and by-products like Husk \& Rice Bran. One of these by-products Husk is used as fuel in steam / power generation in process industries besides being used in Brick manufacturing as burning curator.Ash remains of paddy husk is further used as farm yard manure with additions of some micronutrients. Another by product rice bran contains about $18-20 \%$ of oil content extracted as Rice Bran Oil (RBO) in solvent extraction plants. In Japan RBO is used as edible oil since many years, which is also known as heart oil for its vitamin $\mathrm{E}$ rich content with high smoke point and antioxidant $\sqrt{ }$ - Oryzanol, which possess high nutraceutical value with properties to reduce low density cholesterol absorption in blood, lowering of TSH and skin care. There has been extensive research in Japan on RBO and commercial extraction of $\sqrt{ }$ - Oryzanol. In India till recently the usage of Rice Bran Oil was limited and now with the awareness among the customers it is being used as edible oil which assures not only good health but also economically viable in comparison with other edible oils available in the market.

Table 1: Summary of the main and by products of Paddy

\begin{tabular}{|c|c|c|c|}
\hline Portfolio of Products & Quantity as \% of & Processing Unit & Customers \\
\hline \multicolumn{4}{|c|}{ Main Products of Paddy from Rice Milling } \\
\hline Fine Rice ** & $68-70 \%$ of Paddy & Rice Mills & $\begin{array}{l}\text { Wholesale Dealers } \\
\text { Retailers } \\
\text { Consumers }\end{array}$ \\
\hline Cut Rice & $6-8 \%$ of Paddy & Rice Mills & $\begin{array}{l}\text { Wholesale Dealers } \\
\text { Retailers } \\
\text { \& Packaged Ready food } \\
\text { manufacturers }\end{array}$ \\
\hline \multicolumn{4}{|c|}{ By-products of Paddy from Rice Milling } \\
\hline Husk & $18-20 \%$ of Paddy & Rice Mills & Process Industries* \\
\hline Rice Bran & $6-8 \%$ of Paddy & Rice Mills & Solvent Extraction Plant \\
\hline \multicolumn{4}{|c|}{ Main Product from Solvent Extraction Plant } \\
\hline Rice Bran Oil & $16-18 \%$ of Rice Bran & Solvent Extraction & $\begin{array}{l}\text { Stockists } \\
\text { Retailers } \\
\text { Consumers }\end{array}$ \\
\hline \multicolumn{4}{|c|}{ By-products from Solvent Extraction Plant } \\
\hline Soap Stock/Acid oil & $16-17 \%$ of Rice Bran Oil & Solvent Extraction & Soap Industries \\
\hline De-OiledCake (Spent) & $82-84 \%$ of Rice Bran & Solvent Extraction & Cattle feed industry \\
\hline
\end{tabular}

Source :http://drd.dacnet.nic.in/Status Paper - 05.html

*Process Industries like Solvent Extraction Plants, Sugar Cos, Brick Manufacturing etc., use husk as fuel for power / steam generation. After the usage at these industries, ash remains of husk is used as media for bio composting. Otherwise husk in its original form is rich in fibre and potent source of silica and hence used as cattle feed (husk from partially boiled paddy) or in glass manufacturing industry.

**Paddy varieties with large sized rice without scent (Non-Basmati rice) is used in poha industry, which in turn again produce husk and rice bran. The same rice is used in preparing stuffed rice products but the husk is again used by the same industry as source of fuel.

\section{Government Institutions in support of Agriculture \&Farmers 2.1 Indian Council of Agricultural Research}

The Indian Council of Agricultural Research (ICAR) is an autonomous organisation under the Department of Agricultural Research and Education (DARE), Ministry of Agriculture, Government of India. 
International Journal of Managing Value and Supply Chains (IJMVSC) Vol. 6, No. 1, March 2015

The Council is the apex body for co-ordinating, guiding and managing research and education in agriculture including horticulture, fisheries and animal sciences in the entire country. With $\mathbf{1 0 0}$ ICAR institutes and 70 agricultural universities spread across the country this is one of the largest national agricultural systems in the world.

\subsection{KrishiVigyanKendras (KVKs') /Agriculture Science Centres}

There are 630 KrishiVigyanKendrasin the order of one KVK/district throughout India designed and nurtured by ICAR. Each KVKis situated in a place within a district with all infrastructural facilities, modern agricultural equipment, laboratory and land to demonstrate new techniques and research outcomes in the field to the farmers. Each KVK will consist of wing of agricultural scientists in the field of agriculture, horticulture/ floriculture, fisheries/ agronomy / plant pathology and so on with equipped laboratory, who work with the motive of reducing the time lag betweengeneration of technology at the research institution and its applicationto the location specific farmer fields for increasing production,productivity and net farm income on a sustained basis with the mandate of "Application of technology/products through assessment, refinementand demonstration for adoption"

To achieve the mandate effectively, the following activities areenvisaged for each KVK:

- On-farm testing to identify the location specificity of agriculturaltechnologies under various farming systems.

- Frontline demonstrations to establish its production potentials on the farmers' fields.

- Training of farmers and extension personnel to update theirknowledge and skills in modern agricultural technologies.

- Work as resource and knowledge centre of agricultural technologiesfor supporting initiatives of public, private and voluntary sectorfor improving the agricultural economy of the district.

There are $31 \mathrm{KVKs}$ ' in Karnataka operating in all districts of the state.

\subsection{Karnataka State Department of Agriculture(KSDA)}

The Department of Agriculture has been created mainly to provide Agricultural Extension services to farmers and to transfer the latest technical knowledge to the farming community, introduction of high yielding varieties, laying demonstrations, imparting training to farmers to improve skills \& knowledge to boost up the agricultural Production and productivity.

\subsection{RaitaSamparkKendras (KSKs') : Farmer Facilitation Centres}

The Department of Agriculture established RaitaSamparkKendras at Hobli (Hobli is a cluster of 10-15 villages : each district will have about 20-25 Hoblis) level with the objective of providing updated crop production related knowhow, arrangement of critical agricultural inputs, primary soil and seed testing facilities and arranging interface with public and private sector technologies. These Kendras are established with the objectives

- To provide technical information on crop selection, crop production related know-how, market information etc., to farmers.

- To provide primary seed and soil testing facilities locally.

- To facilitate on site provision of critical inputs like seeds, bio-fertilizers and plant protection chemicals.

There are 747 (as of 2013) KrishiSamparkKendras in Karnataka State

\subsection{National Bank For Agriculture \& Rural Development (NABARD)}

NABARD's role in rural development in India is phenomenal.National Bank For Agriculture \&

Rural Development (NABARD) is set up as an apex Development Bank by the Government of India with a mandate for facilitating credit flow for promotion and development of agriculture, 
cottage and village industries. NABARD operates throughout the country through its 28 Regional Offices and 336 district offices across the country. It refinance the financial institutions like State Co-operative Agriculture and Rural Development Banks (SCARDBs), State Co-operative Banks (SCBs), Regional Rural Banks (RRBs), Commercial Banks (CBs) and other financial institutions approved by RBI which cater to the finance needs of farming community to strengthen rural economy apart from providing these institutions with required training facilities.

\subsection{Regional Rural Banks (RRBs')}

Apart from Commercial Banks and Co-Operative banks working in rural India, RRBs' are established in the year 1975 with an objectiveto develop the rural economy by providing credit facilities for agriculture, trade, commerce, industries and other productive activities in rural areas, particularly to the small and marginal farmers. NABARD regulates and refinances RRBs. There are 6 RRBs and 1184 branches operating across 30 districts of Karnataka.

\section{Review of Literature}

SilpaSagheer, SS Yadav and SG Deshmukh (2009) studied Indian agribusiness to present a conceptual framework and set of propositions to analyse competitiveness of India's agrifoodchain. The framework is dependent on two major streams ofmanagement - value chain analysis (VCA) and strategic competitiveness. Porter's diamond at theindustry level and Momaya's asset-process-performance (APP) model at the firm level provide the basefor competitiveness discussions. They found that, the framework comprises of "human" and "nonhuman" components. They are more likemembers of a network where action of each has an impact on the other. By examining the roles ofhuman components like national government, producers, processors, etc. and non-human componentslike food quality, regulatory scenario, etc. side-by-side, this study breaks new grounds in exploring thesynergy of VCA and competitiveness management.

Raphael Kaplansky (2005) finds on though many countries have gained by globalization, it has brought a rise in inequality within and between countries. He further shows that Value Chain Analysis can be used both to chart the disparity between global economic activity and global income distributionand to provide causal explanation for this disparity.

One of the key dimensions of VCA is "governance". It has become a dominant theme in food value chain discussions in recent years (Gereffi, 1994; Kaplinsky and Morris, 2001; Humphrey, 2006a, b; Dolan and Humphrey, 2004). It indicates the degree of power and defines the strength in a chain's performance. Kaplinksy and Morris (2001) classified it as "legislative", "executive" and "judicial governance" that, respectively, allowed compliance of standards, assisting value chain participants in complying to standards and co-coordinating their compliances.

Lai et al. (2002) distinguished three dimensions of supply chain performance in transport logistics: 1 service effectiveness for shippers; 2 operational efficiency; and 3 service effectiveness for consignees. Within these dimensions they identified four performance indicators: 1 responsiveness; 2 reliability; 3 costs; and 4 assets.

Beamon (1999a, b) (in manufacturing) suggested a system of three dimensions: 1 resources (i.e. efficiency of operations); 2 output (i.e. high level of customer service); and 3 flexibility (i.e. ability to respond to a changing environment). This literature review shows that many efforts have been made to develop a PMS for various supply chains. Despite their importance, little attention has been paid in the literature to integrated PMS.

Aramyan et al. (2006) developed a preliminary conceptual framework of a PMS for agri-food supply chains based on the literature, which captures the characteristics of agri-food supply chain as well as other financial and non- Performance measurement in agri-food supply chains financial indicators. The conceptual framework, consists of four main categories: 1 efficiency;2 flexibility; 3 responsiveness; and4 food quality. 
ChitraSrivastavaDabas, Brenda Sternquist, and HumairaMahi (2012) find out the fact that Government regulations influence the supply chain structure in India. Relational bonds offset the uncertainty borne of weak institutions. Informational transparency and long-term orientation foster trust between channel partners. This trust, in turn, leads to collaborative partnerships.

AJ Higgins, CJ Miller, AA Archer, T Ton, CS Fletcher and RRJ McAllister(2009) in their research paper named Challenges of operations research practice in agricultural value chains found that The relevance and utility of OR in ensuring the success of agricultural value chains into the future will require practitioners to understand and model value chains as complex adaptive systems.

Quah Hock Soon andZulkifli Mohamed (2011) finds that the core flexibility of the value chain can be defined from operational, supply and logistics perspectives where different levels of integration and implementation strategies offer different levels of flexibility response to volume and product mix.

Robert Mason and Chandra Lalwani (2007) in their work on Combining vertical and horizontal collaboration for transport optimization found that New innovative solutions are emerging for better transport optimization, that exploit the competitive power of collaboration, both vertically with supply chain partners and horizontally with other logistics service providers (LSPs).

$M$ Umagowri and $M$ Chandrasekaran (2011) in their study An Economic Analysis of Value Chain of Banana in Western Tamil Nadu brings out the fact that to prevent the post-harvest loss there is need for training in post-harvest handling of fruit bunches; to improve the marketing efficiency, the growers should sell their produce directly to the wholesaler or tie up with the processor or retailer wherever feasible; and farmers must have the latest market knowledge, for taking better sales decision.

Niraj Kumara and Sanjeev Kapoor (2010) in their research "Value Chain Analysis of Coconut in Orissa" finds that, no major value addition is done by the players at any level. The study has observed a high ratio of vendors $\mathrm{v} / \mathrm{s}$ farmers and aggregators $\mathrm{v} / \mathrm{s}$ vendors in the channel. In spite of this high ratio, both vendors and aggregators are able to earn profit and are continuing the business. It is suggested that coconut based industries should be jointly promoted by state industry department, state agriculture department

K VenkataSubaiah, K NarayanaRao, K NookeshBabu (2009) design Supply Chain Network based on Supply Chain Operations Reference (SCOR) model which includes material purchase plan, production plan, inventory plan and transportation plan in a research work on Supply Chain Management in a Dairy Industry. From the results it is observed that the total cost of the supply chain is $9.8 \%$ lesser than the existing cost.

\section{Research Gap}

Though there have been different approaches towards identifying parameters of supply chain performance, models of supply chain efficiency, dimensions of value chain analysis and tracking of value chain to some extent up to first stage consumer for different products (Banana in Tamil Nadu and Coconut in Orissa) in the available literature,there is no complete tracking of all products/by products originating out of chief agricultural produce. So it was found necessary to track the complete value chain for each product originating from an agricultural product paddy (chosen agricultural produce) as it possesses wide portfolio of products for different customers.

\subsection{Objectives}

1. To list out the existing practices of supply chain of paddy and its allied products before and after harvesting.

2. To investigate the factors which influence decision making process of farmer in the perspective of value creation for his produce 
3. To estimate value creation, realization and loss along the value chain of paddy and its allied products

4. To derive conceptual framework ensuring fairvalue realization to the farmer through all stages of supply chain

\subsection{Methodology}

Supply Chain Practices and value chain analysis for pre-harvesting of paddy is generalized based on the earlier research literature available with agricultural universities. Detailed scheme of sampling and analysis is focused to understand post harvest crop management by the farmers and other channel partners till the end of supply chain.

List of 196 farmers cultivating paddy from all districts of Karnataka was obtained (according to probability proportional to total area under cultivation and land holding pattern of farmers in Karnataka) from 31 KrishiVigyanKendras $(\mathrm{KVK})$ operating 1 in each district along with basic macro information of the district on total area under paddy, land holding pattern of farmers, type of soil, water etc., and rating of KVK agricultural scientists about the paddy growing farmers regarding their consultation with KVKs' for seed variety selection, application of fertilizer, type of cultivation, pesticides usage etc.,. Further these farmers were contacted to collect information about their demographic details, their economic condition, decision making behaviour to investigate the factors influencing decision of farmer in generating better value to the produce.

Information about supply chain practices, value loss components, value creation activities and value realization at each stage of processing / stocking is collected through interview with commission agents, stockists, Rice millers, wholesale dealers, solvent extraction plants, retailers across the state.

\section{Analysis and Findings \\ 5.1 Prevailing supply chain practices Stage 1 :Farming}

It is the initial process in the value chain of paddy production. In order to know the Preharvesting value chain of paddy, KrishiVigyan Kendra's (Agriculture Science Centres/ KVKs') set up in each district by ICAR were approached to find out the existing practices of farmers towards cultivation of paddy in the districts. Agricultural Scientists of KVK will coordinate various activities to educate farmers for better agricultural practices and conduct sessions on aspects like recent trends in agriculture, seed selection, cultivation process, mechanization, grading of agricultural produce etc., to the farmers on regular basis. The farmers who are in connection of KVKs are

1. the farmers who approach $\mathrm{KVK}$ with their specific agriculture related problem

2. the progressive farmers of the district as identified by the KVK/ state agriculture department

3. the farmers who are inclined to know and adopt best practices of agriculture

Though the number of farmers who are in the regular network of KVK are about 5-10\% of the total number of farmers in the district, they represent the whole geographical area in the district and inform /implement the learning in their farms and around in their villages. Apart from this, when KVK's scientists visit farmers land to reach out to the farmers in the villages many farmers approach for guidelines and thus making the network of farmers still widerwith KVK. So it was found appropriate to talk to the KVK scientists to know about the components of value chain during the phase of farming. Also the scores (on the scale of $5 ; 5$ being the best) on consulting habit of farmer towards KVK during many value adding stages of farming are noted as follows. 
International Journal of Managing Value and Supply Chains (IJMVSC) Vol. 6, No. 1, March 2015

Table 2: Value driving activities \& consulting tendency of farmers towards KVK scientistsincultivation of Paddy

\begin{tabular}{|c|c|c|c|c|}
\hline \multirow[b]{2}{*}{ Stage 1} & \multirow{2}{*}{$\begin{array}{c}\text { Drivers of value } \\
\text { Chain }\end{array}$} & \multirow[b]{2}{*}{$\begin{array}{l}\text { Supplier / Service } \\
\text { provider }\end{array}$} & \multicolumn{2}{|c|}{ General Rating of farmers by KVK } \\
\hline & & & Opinion & $\begin{array}{l}\text { Avg. } \\
\text { Score }\end{array}$ \\
\hline \multirow[t]{4}{*}{ Farming } & $\begin{array}{l}\text { Selection of Seed } \\
\text { Variety }\end{array}$ & $\begin{array}{l}\text { 1.State Agri. Dept.(RSK) } \\
\text { 2.Private Retail Stores } \\
\text { 3.KVKs }\end{array}$ & $\begin{array}{l}\text { Framers in contact do consult } \\
\text { about seed variety before sowing } \\
\text { Buy seeds from KVK counters } \\
\text { RSKs' }\end{array}$ & 3.82 \\
\hline & Transplantation & $\begin{array}{l}\text { Farmerwith at least } 15 \\
\text { labours/acre/day }\end{array}$ & $\begin{array}{l}\text { Only few (less than } 1 \% \text { ) have switched } \\
\text { to mechanization of paddy } \\
\text { transplantation though it ensures } 20 \text { - } \\
30 \% \text { more yield and high reduction in } \\
\text { labourcost }{ }^{1}\end{array}$ & 1.36 \\
\hline & $\begin{array}{l}\text { Application of } \\
\text { Fertilizers }\end{array}$ & $\begin{array}{l}\text { 1.State Agri. Dept.(RSK) } \\
\text { 2.Approved Private Retail } \\
\text { 3. KVKs }\end{array}$ & $\begin{array}{l}\text { Scientific approach is lagging. } \\
\text { Soil testing is seldom done }{ }^{2} \text {. } \\
\text { But farmers consult }\end{array}$ & 3.52 \\
\hline & Pesticides & $\begin{array}{l}\text { 1.State Agri. Dept.(RSK) } \\
\text { 2. Private Retail Stores } \\
\text { 3.KVKs }\end{array}$ & $\begin{array}{l}\text { Scientific approach is lagging. } \\
\text { Overdose is not under contro }{ }^{3} \text {. } \\
\text { Farmers do consult } \\
\text { About } 1 \% \text { farmers do organic farming }\end{array}$ & 3.32 \\
\hline
\end{tabular}

RSK :RaitaSamparka Kendra (Farmer Facilitation Counters of State Agriculture Department)

\section{Stage 2 :Harvesting}

Harvesting is initiated when moisture content of paddy reduces below $25 \%$ in the farm. It picks up momentum in the following three situations

- $\quad$ farmers harvest paddy at right time, dry it under sun to get the moisture level to about $15-20 \%$ (if stored with moisture of more than $20 \%$, the colour and quality of rice deteriorate ; if dried to less than $15 \%$ moisture, proportion of cut rice will be more in hulling ; Moisture level of $15-20 \%$ is the optimum moisture level) and store it either in the farm house / at their houses waiting for buyers

- $\quad$ harvest paddy once confirming the price with the local agent (buyer) at moisture level acceptable to the buyer(more the moisture, less the price) the price of which will be..

a. equal or little more than the market value for that day if paddy is of good quality and dry (15-20\% moisture)

b. less than or equal to the present market value if moisture seems to be more than the standard.

Table 3 :ValueDrivers and Intermediaries of Stocking Raw Paddy After Harvesting

\begin{tabular}{|c|c|c|c|c|}
\hline Stage 2 & Drivers of value Chain & $\begin{array}{l}\text { Supplier / Ser } \\
\text { provider }\end{array}$ & & Practices / Remarks \\
\hline \multirow{6}{*}{$\begin{array}{l}\text { Harvesting } \\
\text { \& Selling } \\
\text { Raw Paddy }\end{array}$} & \multirow{3}{*}{$\begin{array}{l}\text { Right time of harvesting (\& } \\
\text { Selling) (@ appropriate } \\
\text { moisture level) }\end{array}$} & Large farmers & $10 \%$ & \multirow{6}{*}{$\begin{array}{l}\text { Majority of farmers } \\
\text { sell to the local agents } \\
\text { because } \\
\text { 1. of risk of optimum } \\
\text { moisture content } \\
\text { 2. of no storage } \\
\text { capacity } \\
\text { 3. of on-spot payment } \\
\text { by the agent } \\
\text { 4. of saving on } \\
\text { loading unloading } \\
\text { and paying } \\
\text { brokerage / cess at } \\
\text { APMC }\end{array}$} \\
\hline & & APMC & $30 \%$ & \\
\hline & & Local agents & $60 \%$ & \\
\hline & \multirow{3}{*}{$\begin{array}{l}\text { Storing of paddy for better } \\
\text { selling price }\end{array}$} & Large farmers & $10 \%$ & \\
\hline & & $\begin{array}{l}\text { Stockists/ } \\
\text { dealers }\end{array}$ & \multirow[b]{2}{*}{$90 \%$} & \\
\hline & & $\begin{array}{l}\text { Rice Mill } \\
\text { Owners }\end{array}$ & & \\
\hline
\end{tabular}




\section{Stage 3 :Drying\& Storing}

Some medium and large land holding farmers (about 30\%) store rice after drying it to the optimum moisture level and

- sell in next 3 to 12 months as old paddy attracts more value in the market. OR

- hull the paddy, store it as rice and sell it to the rice stockists and retailers directly (observed in Davangere, Raichur, Bellary, Mysore, Mandya,Koppal and part of Shivamogga districts)

Remaining below medium and small farmers (about 70\%) sell paddy to the local agents directly from the farm.

Local network of agents who collect huge quantity of paddy from farmers during harvesting, sell it to the stockists / Rice millers (In more than $60 \%$ of cases Rice Mills run on partnership of 1015 stockists/rich farmers).

At rice mills, mechanized drying beds / cement yards are available to make the wet paddy (purchased at economic cost from the farmer, bargaining on more moisture, cloudy weather during harvesting etc.,) to its optimum moisture level. It is either stored or milled to get rice and preserved in the form of eatable rice in customized packets of $25 \mathrm{~kg} \mathrm{\&} 50 \mathrm{~kg}$ and sold as per the demand in the market.

\section{Stage 4 :Hulling at Rice Mill (Focal firm 1) \& selling to different customers}

Except about $10-15 \%$ of total paddy produced in the state which is used by poha industry, remaining $85-90 \%$ of produce is hulled in rice mills to get rice \& cut rice as main products and rice bran and husk as by products. For every $100 \mathrm{kgs}$ of paddy hulled approximately we get about $66-70 \mathrm{kgs}$ of rice, $6-8 \mathrm{kgs}$ of cut rice and by products $6-8 \mathrm{kgs}$ of bran and $18-22 \mathrm{kgs}$ of husk. Present cost of hulling is Rs 100/Quintal. The prevailing practice in mills is that they maintain stock paddy for few months so that the newly harvested paddy is made old before being milled (advantage is more recovery of quality rice and better taste when cooked) which attract more value in the market. It is taken for hulling and stored as packaged rice as per the requirement of the stockist or the retail chain customer, sold at premium wholesale price. In the process again agents mediate between mill owners and wholesale dealers of different quality and variety of rice in different market places across the state.

One by-product rice bran is sold to the solvent extraction plant within 2-4 days of processing (more waiting time increase free fatty acids content in the bran, which result in low extractability of rice bran oil) through agencies. If its supply to the extraction plant is delayed by more than a week, it will not be accepted by the extraction plants and hence used directly as a cattle feed by the farmers \& hence sold as cattle feed.

The other by-product husk is sold to the process industries like sugar factories, distilleries, solvent extraction plants and brick manufacturing units, where it is used as fuel to generate steam/ electricity / curing agent.

\subsection{Value addition at Rice Mills}

a. Drying the Paddy to its optimum moisture level - Opportunity to preserve paddy and obtain better value 
International Journal of Managing Value and Supply Chains (IJMVSC) Vol. 6, No. 1, March 2015

b. Waiting time to milling so that only old paddy (preserved paddy for more than 4 months after its harvesting is called old paddy) is milled - scope to enjoy benefits of serving next line customer with good quality rice with better price

c. Modern Rice milling technology - Mechanically cleaned rice ready to cook packaged in customized quantities : again attracting better value from the customer

d. Cut Rice is further used to prepare rice floor / IdliRava / Dosa Mix and packed and marketed (value addition) by local packaged food companies or organized retail chains like More, Big Bazaar and so on.

\subsection{Supply Chain of Rice Bran at Solvent Extraction - Second set of focal firms}

The most valuable by-product from rice milling industry i.e., rice bran (about 6-8\% of total paddy milled) which contains about $16-18 \%$ rice bran oil is a raw material for the solvent extraction unit. In the solvent extraction facility rice bran oil (also known as heart oil for its anti-oxidant property and gamma $(\sqrt{ })$-Oryzanol content which is known to reduce absorption of low density cholesterol into the blood, balance TSH and skin friendly advantages when used as edible oil)is extracted as chief productand de-oiled spent (about 82 to $84 \%$ ) as by-product, which is a rich source of protein used as a chief ingredient in cattle feed preparation. Other by-products are soap stock used by soap manufacturing industries (for its rich content of free fatty acids) and waxes / gums used for coating candy, fruits and vegetables as it prevents moisture loss and shrinkage. Extraction and retention of high value $\sqrt{ }$-Oryzanolfor its pharmaceutical properties from soap stock is an area where lot of research is on since many years in Japan, US and India. So one can expect differential value generation along the supply chain of rice bran processing through rice bran oil, de oiled spent, soap stock, gums and waxes etc.,.(Source : Status Paper-05 at http://drd.dacnet.nic.in)

\subsection{Supply Chain of husk at many Processing Industries : Third set of focal firms}

The bulky by-product from rice milling is its husk (about 20-22\% of total paddy milled). It is a rich source of silica and fibre and hence may be used in glass manufacturing. But it has a considerable fuel value for variety of industries and so largely used as a fuel in process industries to produce steam or electricity. Later its ashes are used as manure as it contains considerable amount of silica, which again is needed in the cultivation of paddy.In this supply chain, value creation happens by using husk as a fuel which saves lot of electricity requirements by the process industries at very cheap cost and the ash remains of husk, which is later used as manure.(Source : Status Paper-05 at http://drd.dacnet.nic.in)

\subsection{Factors influencing farmers' decision in selling paddy after harvesting}

Across the supply chain of paddy, it is observed that the decision process among farmers in deciding seed variety, transplantation, application of fertilizer / pesticide will consume considerate amount of time, energy and money along with many support systems like agricultural department, intervention of agriculture scientists, technology know how to improve productivity and so on. But when it comes to ready crop, farmer decides to sell his produce quickly (more than $60 \%$ of quantity is sold to the network of local agents) in a short span of time during harvesting, for obvious reasons as pointed out in table 3 above.

This move by the farmers of paddy makes them loose a huge opportunity to negotiate for better valuein the rest of the value chain. The influencing factors for such decision viz., land holding pattern, family size, burden of school going children in a family, liabilities in the bank, dependency on other parallel crops, risk associated with crop, storage are tested for possible association using Chi-Square statistic. The results were as follows. 
International Journal of Managing Value and Supply Chains (IJMVSC) Vol. 6, No. 1, March 2015

Table 4 :Factors affecting decision making tendency of farmer during harvesting

\begin{tabular}{|l|l|l|}
\hline Hypotheses & P-Value & Inference \\
\hline $\begin{array}{l}\text { H1: There is no association between Immediate selling } \\
\text { decision of paddy by the farmer and his land holding } \\
\text { pattern }\end{array}$ & 0.000 & $\begin{array}{l}\text { Rejection of H1 } \\
\text { There is strong associations }\end{array}$ \\
\hline $\begin{array}{l}\text { H2: There is no association between Immediate selling } \\
\text { decision of paddy by the farmer and his dependency on } \\
\text { other crops }\end{array}$ & 0.000 & $\begin{array}{l}\text { Rejection of H2 } \\
\text { There is strong association }\end{array}$ \\
\hline $\begin{array}{l}\text { H3: There is no association between Immediate selling } \\
\text { decision of paddy by the farmer and his financial } \\
\text { liabilities }\end{array}$ & 0.005 & $\begin{array}{l}\text { Rejection of H3 } \\
\text { There is strong association }\end{array}$ \\
\hline $\begin{array}{l}\text { H4: There is no association between Immediate selling } \\
\text { decision of paddy by the farmer and his family size }\end{array}$ & 0.333 & $\begin{array}{l}\text { Acceptance of H4 } \\
\text { There is no strong association }\end{array}$ \\
\hline $\begin{array}{l}\text { H5: There is no association between Immediate selling } \\
\text { decision of paddy by the farmer and the number of } \\
\text { children studying in his family }\end{array}$ & 0.054 & $\begin{array}{l}\text { Acceptance of H5There is no } \\
\text { strong association }\end{array}$ \\
\hline $\begin{array}{l}\text { H6: There is no association between Immediate selling } \\
\text { decision of paddy by the farmer and his education }\end{array}$ & 0.288 & $\begin{array}{l}\text { Acceptance of H6There is no } \\
\text { strong association }\end{array}$ \\
\hline
\end{tabular}

Collectively it can be understood that the factors like family size, number of school going children in a family or education level of the farmer do not significantly influence the farmer to sell paddy immediately after harvesting, but factors like land holding pattern (i.e., being small, medium or large farmer), dependency on other parallel crops and financial liabilities (different type of loans raised in banks or other financing sources) of farmers influence farmer to sell of the paddy to the approaching agents immediately after harvesting.

Apart from the above factors, multiple advantages of mitigating risk of maintaining optimum moisture content in paddy, deterioration due to storing at high moisture content / unforeseen rains, saving loading unloading charges, transportation cost, brokerage and cess in driving the produce to APMC yard normally influence farmers to sell the produce to the agents at their farm.

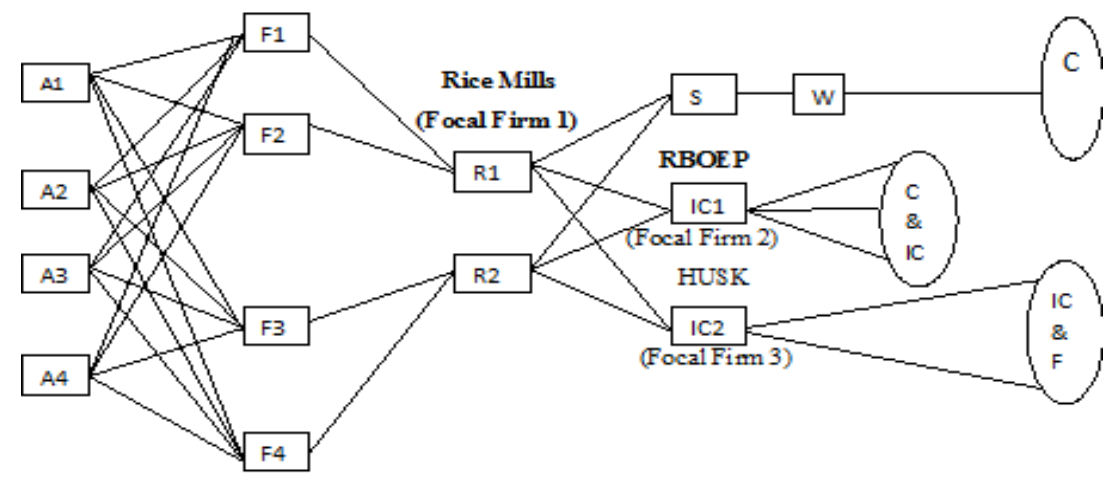

Diagram1 : Process View of Supply Chain of Paddy \& its allied products

A1, A2, A3, A4 : Suppliers / Resource supplements to Agricultural Activities such as (Seeds, Fertilizers, FYM, Pesticides), Finance, Labour, Technical Knowhow

F1, F2, F3, F4 : Farmers from different geographical, economic, education, motivational backgrounds

R1, R2 :1800 Rice Mills (First Focal Firm)

$\mathrm{S}$ : Stockists; W: Wholesalers; C: Consumers of rice and cut rice

IC1 : Industrial Customer 1 (10 Solvent Extraction Plants : Second set of Focal Firm)

RBOEP : Rice Bran Oil (RBO) Extraction Plant

IC2 : Industrial Customer 2 (Many Process Industries : Third set of Focal Firms)

$\mathrm{C} \& \mathrm{IC}$ :Consumer product RBO \& Soap Stock, Wax \& Gums used by further Industrial Customers

IC \&F : Industrial Users \& Farm usage as FYM 
International Journal of Managing Value and Supply Chains (IJMVSC) Vol. 6, No. 1, March 2015

\subsection{Estimation of value created in the supply chain}

The following macro parameters for the year 2011-12 production of paddy in Karnataka state are included

1. Total area under paddy : 1.416 million $\mathrm{Ha}$

2. Average yield of paddy / $\mathrm{Ha}: 4388 \mathrm{Kg}$

3. Average land holding pattern of farmers : $1.55 \mathrm{Ha}$

4. Average outgoing quality and price of paddy Rs. 1606 / quintal is considered (collective for all varieties of paddy cultivated in the state as obtained by weighted average of daily prices of paddy traded through all APMC markets in Karnataka for the year 2012-13)

The following cases of value estimation at different stages of supply chain are excluded

1. Paddy used for poha and puffed rice products is estimated to be about $10 \%$ of the total production and excluded from main supply chain of process.

2. Paddy cultivated under organic farming and paddy stored and sold by farmers either as old paddy after waiting for better price or as packaged rice to the rice stockists and retailers is estimated to be another $10 \%$ of total paddy produced and excluded from main supply chain process.

Table 5 :Value Chain Analysis of Paddy (Till Rice as the end Product)

\begin{tabular}{|c|c|c|c|c|c|c|c|}
\hline Product & From & $T_{0}$ & $\begin{array}{l}\text { \% of } \\
\text { paddy }\end{array}$ & Price $/ Q$ nt & $Q t+x(Q n f)$ & Value (Rs.) & $\begin{array}{l}\text { \% Value } \\
\text { Created }\end{array}$ \\
\hline Paddy at Farm & Farmer & Agent & $\mathrm{NA}$ & 1606 & 49707264 & 79829865984 & - \\
\hline Paddy & Agent & Stockist & $\mathrm{NA}$ & 1686 & 49707264 & 83806447104 & $\begin{array}{c}4.9 \text { (Commission } \\
\text { to agent) }\end{array}$ \\
\hline Paddy to Rice & Stockist & Rice Mill & $\mathrm{NA}$ & 1790 & 49707264 & 88976002560 & $\begin{array}{c}\quad 6.17 \text { (Cost of } \\
\text { milling Storing) }\end{array}$ \\
\hline a) Rice & Paddy & Rice & $67 \%$ & 3500 & 33303867 & $1.1279 \mathrm{E}+11$ & - \\
\hline \multicolumn{8}{|l|}{ b) Levy Rice* } \\
\hline c) Cut rice & Paddy & Cut rice & $8 \%$ & 2000 & 3976581 & 2684192256 & - \\
\hline d) Husk & Paddy & Husk & $18 \%$ & 300 & 8947308 & 5219262720 & - \\
\hline e) Bran & Paddy & Bran & $7 \%$ & 1500 & 3479508 & 7953162240 & - \\
\hline Total (a+b-ctd+e) & Rice Mill & $\begin{array}{l}\text { Mill Owners } \\
\text { (stockists) }\end{array}$ & $\mathrm{NA}$ & $\mathrm{NA}$ & 49707264 & $1.28647 \mathrm{E}+11$ & 44.6 \\
\hline Rice & $\begin{array}{l}\text { Mill } \\
\text { Owner/ } \\
\text { Stockist }\end{array}$ & Agent & & 3450 & 33303867 & $1.14898 \mathrm{E}+11$ & - \\
\hline Rice & $\begin{array}{l}\text { Rice } \\
\text { Stockist }\end{array}$ & Wholesaler & $\mathrm{NA}$ & 3500 & 33303867 & $1.16564 \mathrm{E}+11$ & - \\
\hline Rice & Wholesaler & Retailer & $\mathrm{NA}$ & 3700 & 33303867 & $1.23224 \mathrm{E}+11$ & $\begin{array}{l}5.71 \text { (Commission } \\
\text { to agent) }\end{array}$ \\
\hline Rice & $\begin{array}{l}\text { Unorganized } \\
\text { Retailer- } \\
95 \%\end{array}$ & Customer & $\mathrm{NA}$ & 4200 & 33303867 & $1.39876 \mathrm{E}+11$ & 13.5 \\
\hline Rice & $\begin{array}{l}\text { Organized } \\
\text { Retailer-5\% }\end{array}$ & Customer & $\mathrm{NA}$ & 4600 & 33303867 & $1.53198 \mathrm{E}+11$ & 24.3 \\
\hline
\end{tabular}

* Levy rice quantity and price is regulated by the government from time to time (not a fixed quantity) 
International Journal of Managing Value and Supply Chains (IJMVSC) Vol. 6, No. 1, March 2015

Table 6 :Value Chain in terms of no. of beneficiaries, time invested, Activities / Cost of value addition\& Average earnings per month

\begin{tabular}{|c|c|c|c|c|c|c|}
\hline Product & Beneficiary & $\begin{array}{l}\text { No. of } \\
\text { beneficiaries } \\
\text { (Estimate) }\end{array}$ & Time Days & Price $/ Q$ nf & $\begin{array}{l}\text { Activities/Cost of Value } \\
\text { Addition }\end{array}$ & $\begin{array}{l}\text { Average } \\
\text { Earning/ } \\
\text { Month (Rs.) }\end{array}$ \\
\hline $\begin{array}{l}\text { Paddy at } \\
\text { Farm }\end{array}$ & Farmer & 1827097 & 300 & 1606 & Good Practices of Agriculture & 2553 \\
\hline Paddy & Agent & 60000 & 150 & 1686 & $\begin{array}{r}\text { Networking with farmers \& } \\
\text { stockists }\end{array}$ & 13255 \\
\hline $\begin{array}{l}\text { Paddy to } \\
\text { Rice }\end{array}$ & Paddy Stockists & NA & 300 & 1790 & $\begin{array}{r}\text { Rice mill setting up, } \\
\text { maintenance; Milling \& } \\
\text { Storing Cost }\end{array}$ & \\
\hline $\begin{array}{l}\text { Rice+Cut } \\
\text { Rice + Bran }\end{array}$ & Stockists & NA & 300 & 3450 & $\begin{array}{r}\text { Heavy investment to purchase } \\
\text { and store paddy \&rice; } \\
\text { Packaging as bags of } 25 \mathrm{~kg}, \\
50 \mathrm{~kg}\end{array}$ & NA \\
\hline $\begin{array}{l}\text { Rice+Cut } \\
\text { Rice+Bran } \\
\text { +Husk }\end{array}$ & $\begin{array}{l}\text { Mill Owners } \\
\text { (Stockists) }\end{array}$ & 36000 & 300 & 3450 & $\begin{array}{r}\text { Heavy initial inves tment; } \\
\text { Packaging as bags of } 25 \mathrm{~kg} \\
50 \mathrm{~kg}\end{array}$ & $116053(110197)^{8}$ \\
\hline Rice & Agent & 60000 & 150 & 3500 & $\begin{array}{r}\text { Networking with wholes ale } \\
\text { merchants }\end{array}$ & 5551 \\
\hline Rice & Wholesaler & 36000 & 300 & 3700 & $\begin{array}{l}\text { Heavy Inves tment to purchase } \\
\text { and store rice; Networking } \\
\text { with mill owners and agents }\end{array}$ & 18502 \\
\hline Rice & $\begin{array}{l}\text { Unorganized } \\
\text { Retail }(95 \%)\end{array}$ & NA & NA & 4200 & Networking with Wholesalers & NA \\
\hline Rice & $\begin{array}{l}\text { Organized Retail } \\
(5 \%)\end{array}$ & NA & NA & 4600 & $\begin{array}{r}\text { Customizedpacking, } \\
\text { Branding }\end{array}$ & NA \\
\hline
\end{tabular}

* Figures inside parenthesis indicate Average Earning/month in the case of selling levy rice to the Govt at the price fixed by the Govt. (In 2012-13, 1.5 lakh MT of levy rice was sold @ Rs. 2044.4/Quintal ofrice) The above analysis can be graphically visualized as follows in terms of

1. Change of unit value of the product at each stage of the supply chain

2. Value gain to each of the stakeholders in the supply chain

3. Earning/month of stakeholders in the supply chain

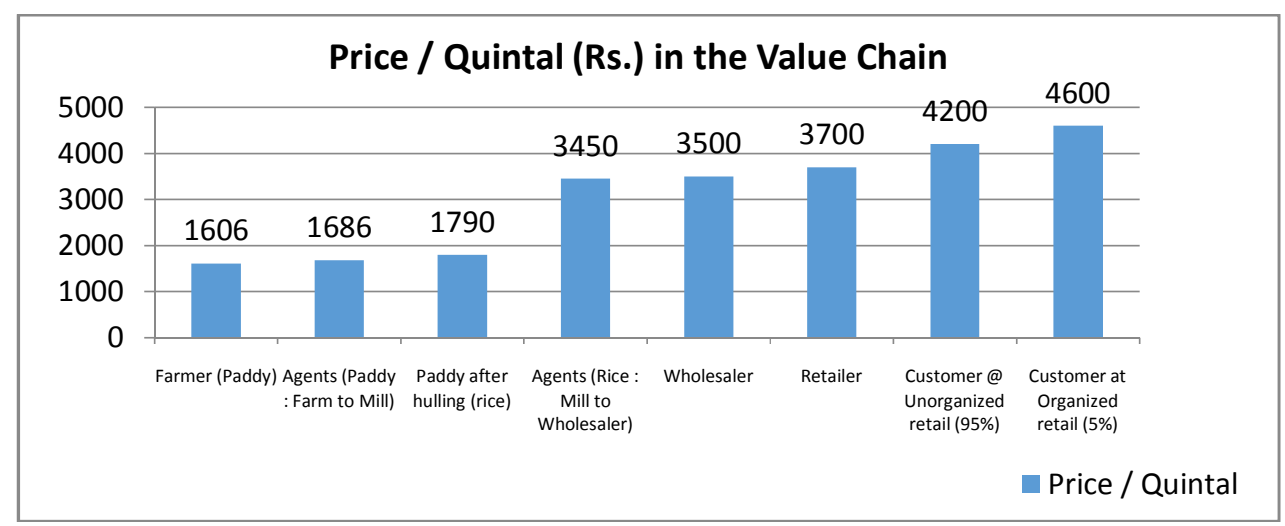

Diagram 2 : Value appreciation at each stage of supply Chain 


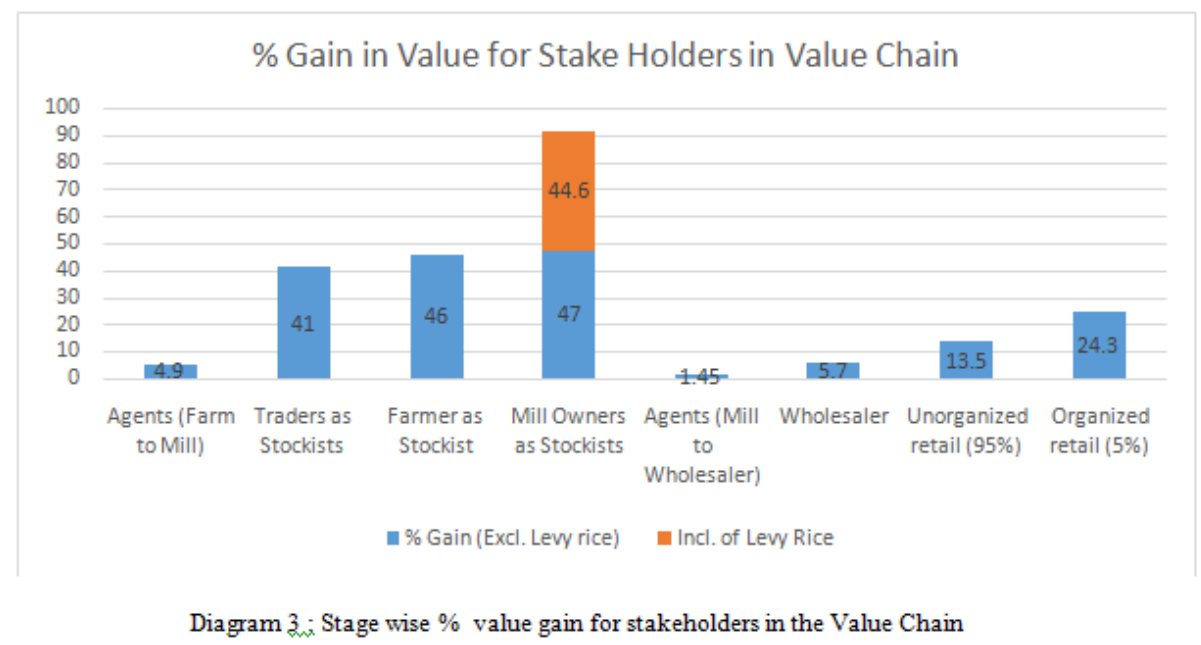

Note that subdivided bars in the above chart indicate $\%$ gain to the respective Mill Owners

1. in absence of levy rice purchase from the state government (in blue )

2. in the case govt. purchase rice from stockists (in orange)

Levy rice quantity purchased by the government from rice mills will not be constant. It was 1.5 lakh MT at Rs 2044.4/Quintal for the year 2012-13.

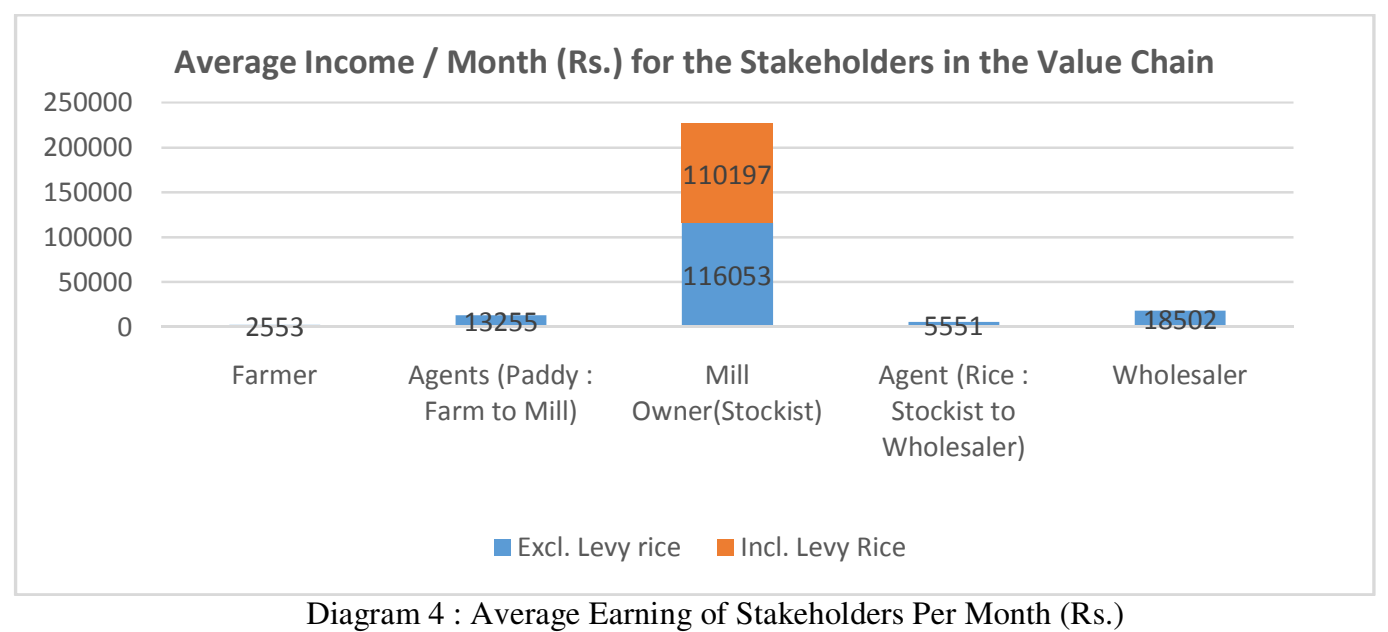

Note that subdivided bars in the above chart indicate $\%$ gain to the respective Rice Mills (Exclusive Stockist)

1. in absence of levy rice purchase from the state government (in blue)

2. in the case govt. purchase rice from stockists/rice mills (in orange)

\subsection{Estimate of value creation at Solvent Extraction Plant using Rice Bran}

There are about 10 Solvent Extraction Plants in Karnataka extracting rice bran oil. Better extractability of oil depends on good milling process and supply of rice bran within 4-6 days soon after its recovery from milling process. So Solvent extraction plants check for the extractability percentage before accepting the bran lot. Because of this reason, whole quantity of rice bran produced in rice mills do not reach extraction facilities (very less in no. against no. of rice mills, which are about 1800 in the state\& distantly placed in wide geographical area) and hence used by the farmers as cattle feed. 
International Journal of Managing Value and Supply Chains (IJMVSC) Vol. 6, No. 1, March 2015

National estimate of usage of rice bran for oil extraction is about $35 \%$ only. However in Karnataka, the solvent extraction plants which are operating are having average capacity of processing about $100 \mathrm{MT}$ of Rice Bran/day and they accept rice bran of required quality irrespective of from where the bran is procured. Thus it becomes very difficult to ensure how much rice bran is used from the state's rice production.

Therefore the value chain estimates are based on the capacity utilized (100MTx10 Unitsx300days) by the existing solvent extraction plants.

Table 7 : Value Chain Analysis at Solvent Extraction Unit (Focal firm 2)

\begin{tabular}{|l|r|r|r|}
\hline Product & Qtty(MT) & \multicolumn{1}{l|}{ Price (Rs.) } & \multicolumn{1}{c|}{ Value (Rs.) } \\
\hline \hline Total paddy production & 6213408 & & \\
\hline Total Bran & 434939 & & \\
\hline Actual usable Rice Bran & 300000 & 17500 & 5250000000 \\
\hline Rice Bran Oil (RBO) & 48000 & 62000 & 2976000000 \\
\hline Soap Stock & 7680 & 20000 & 153600000 \\
\hline Wax \& Gum & 960 & 5000 & 4800000 \\
\hline Spent & 252000 & 12000 & 3024000000 \\
\hline
\end{tabular}

Net Value Gained by the RBO Industry / Year $\quad 908400000$

Net Value Gained / RBO Extraction unit

90840000

Wholesales Margin Rs. 5/kg of RBO

Retailers Margin Rs. 3/kg of RBO

\subsection{Estimate of value creation by rice husk}

Husk is used by many industrial users like solvent extraction plants, Sugar mills and Brick manufacturing units as fuel.

Table 8: Value Chain Analysis of Rice Husk (Focal firm 3)

\begin{tabular}{|l|r|r|r|}
\hline \multicolumn{1}{l}{ Product } & \multicolumn{1}{c}{ Qtty(MT) } & \multicolumn{1}{c|}{ Price (Rs.) } & \multicolumn{1}{c|}{ Value (Rs.) } \\
\hline \hline Total paddy production & 6213408 & & \\
\hline Total Husk & 1118413 & 20000 & 22368268800 \\
\hline Efficiency (1.3*) & & & 29078749440 \\
\hline Ash (used as organic manure) & 223682.688 & 3000 & 671048064 \\
\hline & & & \\
\hline Value Gain to the industries using husk & & & $\mathbf{3 3 \%}$ \\
\hline
\end{tabular}

*Efficiency 1.3(in terms of worth of Electricity Produced) means for every Rs. 1000 spent on husk saves electricity/power worth Rs 1300

Note : Estimates of further value addition using soap stock from solvent extraction plant and synthesis of $\sqrt{ }$ - Oryzanol is not included in the study. 
International Journal of Managing Value and Supply Chains (IJMVSC) Vol. 6, No. 1, March 2015

\subsection{Practices that lead to value loss in Supply Chain of Paddy}

Table 9 :Practicesleading to the value loss in the supply chain of paddy

\begin{tabular}{|c|c|c|}
\hline Stage & $\begin{array}{l}\text { Practices of Value / Opportunity } \\
\text { Loss }\end{array}$ & Remark \\
\hline Farming & Mechanized transplantation is as less as $1 \%$. & $\begin{array}{l}\text { Loss of about } 30 \% \text { yield; } \\
\text { Cost of mechanization is high } \\
\text { even with } 50 \% \text { Govt. subsidy }\end{array}$ \\
\hline Harvesting & $\begin{array}{l}\text { More than } 65 \% \text { of harvested paddy is sold } \\
\text { to local agents / mill owners leaving large } \\
\text { scope of revenue \& gain by not reporting to } \\
\text { APMC }\end{array}$ & $\begin{array}{l}\text { This is a robust process; only a } \\
\text { transparent, bureaucratic } \\
\text { governance incorporated with the } \\
\text { existing system can bring about } \\
\text { change }\end{array}$ \\
\hline $\begin{array}{l}\text { Milling \& } \\
\text { Storage }\end{array}$ & $\begin{array}{l}\text { Govt. storage capacities are limited \& hence } \\
\text { rice mills by and large act as warehouses for } \\
\text { both harvested paddy and ready rice. Thus } \\
\text { rice millers/ stockists act as virtual bodies in } \\
\text { fixing/varying the prices of rice }\end{array}$ & $\begin{array}{l}\text { Mostly Rice Mills are managed } \\
\text { by large farmers / stockists. Govt. } \\
\text { warehouses at villages also } \\
\text { occupied by large } \\
\text { farmers/stockists }\end{array}$ \\
\hline Usage of bran & $\begin{array}{l}\text { About } 50 \% \text { of bran is not utilized by } \\
\text { Industries to produce rice bran oil as there is } \\
\text { no standard protocol }\end{array}$ & $\begin{array}{l}\text { The increasing free fatty acid } \\
\text { content in rice bran is hardly } \\
\text { cared by rice millers as the value } \\
\text { for rice bran do not much vary if } \\
\text { it goes for extraction or cattle } \\
\text { feed }\end{array}$ \\
\hline Usage of Husk & $\begin{array}{l}\text { No Standard protocol. Lifted by } \\
\text { parties/industries as and when required }\end{array}$ & Rice mills can be augmented \\
\hline $\begin{array}{l}\text { Usage of Rice } \\
\text { Bran Oil as } \\
\text { edible oil }\end{array}$ & Limited due to less awareness & $\begin{array}{l}\text { Initiatives of propagating } \\
\text { awareness is lacking; } \\
\text { Collaboration for R\&D in } \\
\text { recovering Gamma-Oryzanol } \\
\text { from soap stock need more } \\
\text { attention }\end{array}$ \\
\hline
\end{tabular}

\section{ConceptualModel for Value creation in the Supply Chain of Paddy}

Looking into the potential value loss stages in the whole supply chain of paddy from farmer to end consumer, the model focuses on striking a win-win balance among all stakeholders of the supply chain viz., farmer, government and caretaker / value driving mechanism of agents, mill owners and stockists.

Owing to the socio economic conditions of the Indian farming community, land holding pattern and farmers approach towards agriculture in the fast changing scenario of globalization, the present study reveals disproportionate wealth distribution to the stakeholders across the value chain. It can be observed from the table no (6) above that farmer gets a monthly income of about Rs.2553 whereas all other stake holders get much higher income in the value chain, the highest income being shared to the mill owner/stockists of course for their huge investment, mobilization of resources at right time during harvest and post harvest period maintaining requisite quality of the food grain till it is served to the end user against certainly payable risk. But if we take a look at the constituents of the body "Mill Owners/Stockists", it includes large farmers, mill owners and a network of agents who work among the farmers to buy their produce at farm level at fairly opportunistic cost and enhance its value manifold through stocking and milling. This stocking and 
milling of paddy do not require any cold storage or expensive method, but a wise decision of when to stock and a voluminous space to stock. Since rice is a staple food and cultivated across huge geographical area, providing such stocking facility by any governmentuniformly across the state is very difficult and hence there is no much intervention of the government in the buying, stocking and milling process of paddy except some generic guidelines by APMCs' regarding fair pricing of commodity, its selling etc., which are still given a lot of relaxation in safeguarding the interests of farmers.(...this is noticed in the fact that more than $65 \%$ of harvested paddy reach the mill owners/stockists without intervention of APMC).

So being the reality, the body "Mill Owners/Stockists" in the supply chain of paddy is an intermediary who predominantly takeover the power of fixing price of this commodity by holding stock and virtually commanding the rest of the value chain.If we look at the macro level, the operations carried out by this intermediary is highly commendable not only for the timely care and support extended through a network of people but also for the fact that the amount of transaction that take place in buying the paddy every year is almost equal to the total amount of state agriculture budget for an year.

Looking back to the intents of Governments, agricultural universities, efforts of scientists\& agricultural departments, the importance is to increase crop yield, devise mechanisms to educate farmers, bringing out best of the best inventions to reach farmers go in vein if the system develops supply chain intermediary like "Mill Owners/Stockists" who grab very high value across the chain leaving the farmers with very thin returns.

If we look at the alternatives of making change in the process, only bureaucratic e governance with public private partnership comes to rescue. The present "Mill Owners/Stockists" intermediary to be taken into confidence but the powers are to be legalized. The amount of value addition through each intermediary to be prefixed. If the government involves itself in the process, the returns can be used directly to improve the standards of farmers by providing technical support, mechanized farming equipments which not only improve the yield of paddy by over $20-30 \%$, but also change the outlook of the farmer drastically as the return in this process is very voluminous that otherwise goes to very few mill owners/large farmers who rarely involve themselves in any activities of giving anything back to farmers. (there is no mandate for CSR activities for Rice Mills).

So the proposed model assumes following instruments in place

- Public Private Partnership (PPP) for buying, storing, milling of paddy and dispatch of rice : The present mechanism/network among farmer-agent-rice mill owner during harvesting for buying, storing, milling of paddy make a private entity (i.e., referred to as "Mill owners \& Stockists") in the PPP model which owns 50\% of the process and Govt./a firm nominated by the government will have ownership of remaining 50\%

- Farmer ID / Kisan ID unique electronic ID with RFID technology : It is an one point information provider for all agriculture related information about the farmer. This will contain demographic and agriculture related information like total land, land being used for paddy \& other crops, type of land, irrigation facility etc., which help in estimating the crop yield accurately and data generated may further be used for other purposes.

- Rice mills to be digitally controlled and be designated as Strategic Business Units(SBUs') where consolidation of paddy, rice and other related product quantities take place which in turn help in avoiding un accounted quantity losses that deliberately happen in the existing supply chain to save service charges levied by APMC or to gain power by the intermediaries.

- No buying from APMC as it is quite difficult to monitor the actual transaction of paddy after harvestingat one point

- Collection of service chargesby APMC must happen at rice mills after reconciling the quantity produced by each farmer as per the data recorded through Kisan ID (i.e., the 
total area under cultivation, average yield and quantity should match), which may require personnel from APMC (or device an automated system) to digitally record receipt of paddy at rice mills from each farmer and continuously track this quantity against its estimate made by the agriculture department.

- Originating products/by products to be tracked for quantity and value across the supply chain

- Profit sharing 50:50

- The focal firms to be tagged for activities that help farmers through CSR initiatives

- Fixing the price of rice should be scientific covering all costs of stocking, milling, packing and preserving such that the margin do not ethically exceed the $\mathrm{B}: \mathrm{C}$ ratio of the farmer.(i.e., if overall B:C ratio is 1.3, the price of rice should not cross $30 \%$ in its value after buying from the farmer).

The difference in the amount created due to present market price and the fair price gives a huge return in the tune of about $20 \%$ of investment, which is a large wealth enough to feed longstanding needs of farmers of not only paddy but of many other crops. This if practiced for 3-5 years can bring sea change in the lives of farmers.

This wealth creation is possible only with paddy as this is the only basic food grown and consumed in high volume which primarily goes through milling and need high care during and after harvesting by the people involved and hence a huge scope for value creation.

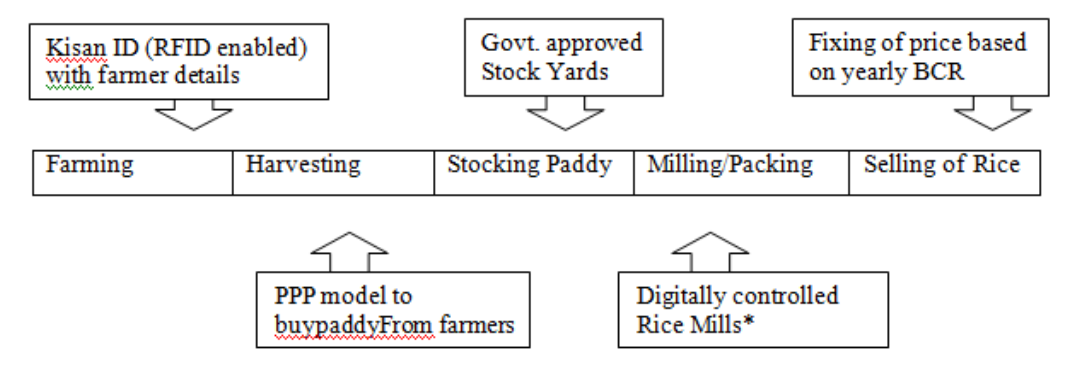

*Rice mills (focal firm 1) are to be declared as strategic business units (SBU) of paddy processing and be controlled electronically for all transactions related to paddy (i.e., quantities of receipt and despatch of paddy, rice and other by-products), which ensures free andfaircollection of cess by the government and also to be monitored for preservation and timely dispatch of rice bran to solvent extraction plants and proper tracking of husk quantities.

Focal firms 2 (Solvent Extraction Plants) and next order focal firmslike soap manufacturing industries and / or other product innovation processes (like synthesis of $\sqrt{ }$-orizanol) are to be tagged for CSR activities directed towards well being of farmers based on the value addition that take place at these firms.

A glance at the possible return using the above proposed model is as follows (for the year 201213).Fromtable 5 above, we get the following extracts.

\begin{tabular}{|c|l|c|}
\hline A & $\begin{array}{l}\text { Total investment (in Rs.) by “Mill Owners / Stockists" in } \\
\text { the supply chain of paddy in a year } \\
\text { (from Buying of Paddy to Stocking and Milling) }\end{array}$ & $\mathbf{8 8 9 7 6 0 0 2 5 6 0}$ \\
\hline B & Total value (in Rs.) of all products after milling process & $\mathbf{1 2 8 6 4 7 0 0 0 0 0 0}$ \\
\hline C & $\begin{array}{l}\text { Total value (in Rs.) generated by "Mill Owners / Stockists" } \\
\text { (B-C) }\end{array}$ & $\mathbf{3 9 6 7 0 9 9 7 4 4 0}$ \\
\hline D & $\begin{array}{l}\text { If Public-Private-Partnership model is in place, the annual } \\
\text { wealth created (in Rs.) by the Govt. (on 50:50 share basis) } \\
\text { through the supply chain of paddy [i.e., C/2] }\end{array}$ & $\mathbf{1 9 8 3 5 4 9 8 7 2 0}$ \\
\hline
\end{tabular}


International Journal of Managing Value and Supply Chains (IJMVSC) Vol. 6, No. 1, March 2015

Thus proposed model if implemented is an opportunity for wealth creation worth of approximately Rs. 2000 crores per year to the government through PPP.

\section{Summary of Findings}

a) Existing practices in supply chain of paddy

Paddy has a longest supply chain as it involves issues like huge geographical area under cultivation, voluminous by nature, quality sensitive during and after harvesting, milling and storing due to which there are many intermediaries in the chain who try to explore possibilities of making individual profits across the supply chain. In the process, it is observed that only $30-35 \%$ of farmers sell paddy through APMC and almost many farmers avoid selling through APMC as it saves cost on transportation as well.The network / groupof"mill owners and large farmers(stockists)" farm the biggest and powerful intermediary in the whole supply chain who account for value generation worth of about $44.6 \%$ of their investment done in the form of buying of paddy from farmers at source, storing, milling and packaging for retail.

b) Factors influencing farmer to sell paddy to local agents

The riskfactors that influence farmer to sell paddy to local agents/mill owners are inadequate storage space, risk of moisture content of paddy during and after harvesting, uncertain weather conditions and fluctuating prices. Apart from these factors, socio-economic factors like land holding pattern $(\mathrm{p}=0.000)$, dependency on other crops $(\mathrm{p}=0.000)$ and financial liabilities $(\mathrm{p}=0.005)$ do influence farmer to sell paddy to local agent soon after harvesting. Whereas family $\operatorname{size}(\mathrm{p}=0.383)$, number of children getting education in a family $(\mathrm{p}=0.054)$ and education of farmer $(p=0.288)$ were found to bear no influence on selling decision of farmer soon after harvesting. Other benefit factors of farmer selling paddy to local agents are saving on transportation, loading and unloading charges of paddy from the farm to market yard / APMC and equal or slightly better price than the price prevailing in the market (not always assured...sometimes even lesser than the market price in case the agent is able to convince the farmer) and avoidance of risk due to quality deterioration in storage.

c) Factors influencing value loss and value creation in the supply chain

At farm level, it was found that there is ahigh loss of yield due to the method of manual transplantation (Avg. Score of 1.9 out of 5), which is practiced by $99 \%$ of farmers. Mechanized transplantation of paddy results in 20-30\% higher yield with reduced labour, which is being practiced by $1 \%$ of farmers in the state. Though the outcome is encouraging, farmers are reluctant to go for mechanization as the equipment costs about Rs.500000 at 50\% subsidy by the govt. Other factors such as choosing of fertilizers, pesticides in consultation with respective KVK officialshasa score of 3.3 to 3.7 on for 5 . After harvesting of paddy, the highest value generation of about $46 \%$ is observed after milling. Further value additions using the by-products such as cut rice, bran and husk are respectively about $10 \%, 17-20 \%$ and $20-30 \%$.

d) Conceptual model for better governance of paddy supply chain

Looking into the overall value chain of paddy and its products, it is found that despite government policies, agricultural and financial institutions' effort to make the farming communityself reliant and more economically stable, farmer remains to be the least paid (Rs. 2553/month) individual. Other intermediaries of the supply chain viz., commission agents, mill owners, stockists and wholesalers are paid much higher than that of farmer. This may be attributed to the land holding pattern, high population of farming community, financial risk taken by intermediaries etc.,. But it is equally important to see whether the system is being overridden by the intermediaries. It is found that about $65-70 \%$ paddy is sold by the farmers directly to the agents of millers/stockists bypassing APMC i.e., loss of revenue to the government or letting the intermediaries build their power to bargain. Though there are instruments like collecting service charge at rice mills and buying levy rice from rice mills/stockists by the government, they are incomplete in totality. So a conceptual model which uses technology for information flow and e- 
International Journal of Managing Value and Supply Chains (IJMVSC) Vol. 6, No. 1, March 2015

governance across the supply chain and Public-Private-Partnership in buying paddy after harvestingis suggested. Using the model, the supply chain of paddy and allied products is expected serve the farmer as well as government in generating periodic wealth which can bring sea change in agricultural development of the whole state.

\section{Conclusion}

Paddy being the main food crop, it is grown on largest geographical area in the state. The money transaction that take place every year in buying paddy from farmers after harvesting is an amount (approximately Rs. 8000 crores) almost equivalent to the state's annual agriculture budget and the value addition that take place in the value chain is about $45 \%$ before reaching wholesaler in the supply chain. However the benefit of this value addition is by and large credited to the efforts of intermediaries who initiate buying of paddy, stocking, milling and packing with the help of a strong network of agents, mill owners and large farmers/stockists. In the process farmer is the lowest paid stakeholder though being the source of supply chain activity. It is also found that because of the vastness of supply chain, government is continuously losing revenue due to service charges from buyers as above $65 \%$ od paddy is sold by the farmer to the open market bypassing APMC. Since the amount and the value addition involved in the supply chain of paddy are huge, it is suggested in this study that it can be supported by the government through PPP model with the usage of technology and digitally controlled rice mills (declared as SBUs) which can act as a source of periodical wealth generation(approximately Rs. 2000 crores / year) besides creating a well systemized e-governance in managing vast supply chain of paddy and its allied products.This wealth can be used to raise the standards of whole farming community in providing them with best possible facilities in terms of information, technology and mechanization needed to meet today's changing needs of global economy.

\section{Acknowledgements}

The authors would like to thank all respondents who were farmers and officials from various government agriculture departments, KVKs' and APMCs' who spent their valuable time and shared relevant information in completing this research work.

\section{References}

1. SilpaSagheer, SS Yadav\& SG Deshmukh, International Journal of Emerging Markets Vol. 4 No. 2, 2009, pp. 137-159

2. Kevin Burgess, Prakash J Singh, RanaKoruglu, International Journal of Operations \& Production Management, Vol. 26 No. 7, 2006, pp. 703-729

3. ChitraSrivastavaDabas, Brenda Sternquist, HumairaMahi ; Organized retailing in India: upstream channel structure and management: ; Journal of Business \& Industrial Marketing Volume: 27 Issue: 32012

4. Lusine H. Aramyan, Alfons G.J.M. Oude Lansink, Jack G.A.J. van der Vorst and Olaf van Kooten, Wageningen University, Wageningen, The Netherlands ; Performance measurement in Agri-food supply chains: a case study ; Supply Chain Management: An International Journal 12/4 (2007), pp. 304-315

5. AJ Higgins, CJ Miller, AA Archer, T Ton, CS Fletcher and RRJ McAllister; Challenges of operations research practice inagricultural value chains ; Journal of the Operational Research Society (2010) 61, pp. 964-973. doi:10.1057/jors.2009.57, Published online 20 May 2009

6. Quah Hock Soon Intel Technology Sdn. Bhd., Penang, Malaysia, and Zulkifli Mohamed Udin College of Business, Universiti Utara Malaysia, Sintok, Malaysia; Supply chain management from the perspective of value chain flexibility: an exploratory study : Journal of Manufacturing Technology Management Vol. 22 No. 4, 2011 pp. 506-526

7. Robert Mason Lean Enterprise Research Centre and Innovative Manufacturing Research Centre (CU-IMRC), Cardiff University, UK; Chandra Lalwani , Business School, The University of Hull, Hull, UK, and Roger BoughtonMultiServ. Logistics, Willenhall, UK; Combining vertical and horizontal collaboration for transport optimization : Supply Chain Management: An International Journal 12/3 (2007) 187-199 
International Journal of Managing Value and Supply Chains (IJMVSC) Vol. 6, No. 1, March 2015

8. $M$ Umagowri and M Chandrasekaran; An Economic Analysis of Value Chain of Banana in Western Tamil Nadu : ICFAI University Press (2011)

9. Niraj Kumara and Sanjeev Kapoor Rural Management Division, Xavier Institute of Management, Bhubaneswar - 751 013, Orissa Indian Institute of Management, Lucknow, Uttar Pradesh ; Value Chain Analysis of Coconut in Orissa ; Agricultural Economics Research Review Vol. 23, 2010 pp 411-418

10. K VenkataSubaiah, Member, IAENG, K NarayanaRao, K NookeshBabu; Supply Chain Management in a Dairy Industry - A Case Study ; Proceedings of the World Congress on Engineering 2009, Vol 1; WCE 2009, July 1-3, 2009, London, U.K.

11. WaiPeng Wong, UniversitiSains Malaysia, Malaysia, Kuan Yew Wong, UniversitiTeknologi, Malaysia; Value Chain performance measurement: A simple DEA analysis using intermediate measures :Review of Business Research, Vol 10, Nov 2010 pp. 129-132

12. Timoothy J Lowe, Poul V Preckel; Decision technologies for Agri Business problems:A brief review of selected literature and a call for research; Manufacturing and Service Operations Management,Summer 2004, Vol. 6 No. 3; pp 201-208

13. H.S Vijayakumar; Changing Ethos of Agribusiness; Readings in Agri Business Management Excel India, 2011; pp.1-24

14. Supply Chain Excellence:A Handbook for Dramatic Improvement Using the SCOR Model, Volume 1(2009, AmacomPublications) ; Peter Bolstorff, Robert G. Rosenbaum

15. Fully revised estimates of Principal Crops in Karnataka for the year 2009-10: Directorate of Economics and Statistics, Karnataka State, Bengaluru.Pp24-29.

16. List of Factories and Agro Processing Units in Karnataka: Directorate of Factories \& Boilers in Karnataka, KarmikaBhavana, Bengaluru.

17. http://www.krishimaratavahini.kar.nic.in

18. http://raitamitra.kar.nic.in/Karnataka\%20State\%20Profile\%202013.pdf

19. http://www.rkmp.co.in

20. http://www.costofcultivationkarnataka.in/bangaloreCircle.html\#

21. http://eands.dacnet.nic.in/Cost_of_Cultivation.html

22. http://raitamitra.kar.nic.in/ENG/index.asp

\section{Authors}

\section{Nagaraj BV}

Asst. Professor, FM n the Area of Statistics\& Operations

Kirloskar Institute of Advanced Management Studies, Harihar, Karnataka, INDIA

Dr. Y T Krishnegowda

Professor \& HOD of Management Sciences; Ex-Director of AICTE, New Delhi \&

Chief Mentor \& Secretary in Governing Council of Maharaja Institute of Technology, Mysore, Karnataka, INDIA
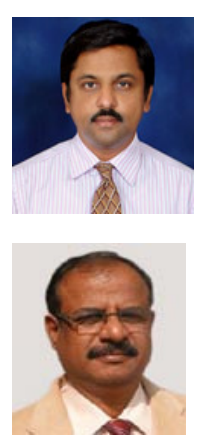